\title{
Strategi Pembelajaran Pendidikan Agama Kristen Pada Anak Usia Dini
}

\author{
Kalis Stevanus, ${ }^{1}$ Dwiati Yulianingsih, ${ }^{2}$ \\ 1,2,Sekolah Tinggi Teologi Tawangmangu \\ ${ }^{1}$ kalisstevanus91@gmail.com
}

\begin{abstract}
Learning strategies are very important as a means of carrying out the learning process so that learning objectives are effective and learning materials can be absorbed properly by students. Learning will not be effective if the learning strategy is not suitable for the situation of the students. Early Childhood Education (PAUD) has unique characteristics, namely in the form of direct activities and various situations related to concrete interests and experiences that can be observed with motor activities. By using a descriptive qualitative approach, this article is intended to describe four learning strategies that can be applied to teach Christianity in Early Childhood, namely edutaintment learning strategies, expository learning strategies; problem-based learning strategies and learning strategies through storytelling.
\end{abstract}

Key words: early childhood; Christian education; learning strategies

Abstrak: Strategi pembelajaran sangatlah penting sebagai sarana untuk melakukan proses pembelajaran agar tujuan pembelajaran menjadi efektif dan materi pembelajaran dapat diserap dengan baik oleh anak didik. Pembelajaran tidak akan efektif bila strategi pembelajarannya tidak cocok dengan keadaan peserta didiknya. Pendidikan Anak Usia Dini (PAUD) memiliki karakteristik yang unik, yakni berupa aktivitas langsung dan pelbagai situasi yang berkaitan dengan minat dan pengalaman yang konkrit yang dapat diamati dengan aktivitas motorik. Dengan menggunakan pendekatan kualitatif deskriptif, artikel ini dimaksudkan untuk mendeskripsikan empat strategi pembelajaran yang dapat diterapkan untuk mengajarkan Agama Kristen pada Anak Usia Dini, yaitu strategi pembelajaran edutaintment, strategi pembelajaran ekspositori; strategi pembelajaran berbasis masalah dan strategi pembelajaran melalui mendongeng.

Kata kunci: anak usia dini; pendidikan agama kristen; strategi pembelajaran

\begin{tabular}{llll}
\hline Article History : & Received: 08-04-2021 & Revised: 04-06-2021 & Accepted: 08-06-2021
\end{tabular}

\section{Pendahuluan}

Anak merupakan berkat sekaligus warisan Tuhan yang harus dirawat dan dididik. Mereka merupakan generasi penerus dari sebuah Negara dan juga Gereja. Salah satu kualitas sumber daya manusia (SDM) mendatang ditentukan pada masa pertumbuhan dan perkembangannya sejak usia dini. Masa usia ini sangat menentukan bagi pembentukan diri anak menuju kematangan iman dan kepribadian. 
Pendidikan pada Anak Usia Dini merupakan pendidikan yang sangat mendasar dan strategis karena masa usia ini merupakan masa emas (golden age) dan peletak dasar (fondasi awal) bagi pembentukan kepribadian manusia secara utuh. Konsep dasar mengenai nilai-nilai kekristenan harus ditanamkan kepada anak-anak sedini mungkin. Sejak dini mereka diperkenalkan pada pengajaran Alkitab maupun pengenalan akan Tuhan Yesus setiap hari dan terus menerus agar firman Tuhan tersebut berakar dan berbuah di dalam diri anak-anak. Anak-anak perlu dibiasakan untuk mengalami dan mengerti nilai-nilai kristiani. ${ }^{1}$

Pendidikan pra sekolah menurut Peraturan Pemerintah No.27 tahun 1990 tentang Pendidikan Pra Sekolah, bahwa program kegiatan belajar anak usia dini meliputi aspekaspek sebagai berikut: moral, nilai-nilai religius, disiplin, kemampuan berbahasa, daya pikir, daya cipta, emosi, kemampuan bermasyarakat sosial, ketrampilan, dan jasmani. ${ }^{2}$

Menurut UU Nomor 20 Tahun 2003 pasal 1 butir 14 tentang Pendidikan Anak usia Dini menyatakan bahwa pendidikan Anak Usia Dini adalah suatu upaya pembinaan yang ditujukan kepada anak sejak lahir sampai dengan usia enam tahun yang dilakukan melalui pemberian rangsangan pendidikan untuk membantu pertumbuhan dan perkembangan jasmani dan rohani agar anak memiliki kesiapan dalam memasuki pendidikan lebih lanjut. ${ }^{3}$ Khususnya di pasal 28 dikatakan bahwa PAUD diselenggarakan sebelum jenjang pendidikan dasar. PAUD dapat diselenggarakan melalui jalur formal, nonformal dan/atau informal. PAUD pada jalur formal berbentuk Taman Kanak-Kanak, atau bentuk lain sederajat. PAUD pada jalur nonformal berbentuk Kelompok Bermain, Tempat Penitipan Anak atau bentuk lain sederajat. PAUD pada jalur pendidikan informal berbentuk pendidikan keluarga atau yang diselenggarakan oleh lingkungan. ${ }^{4}$

Dalam pengelolaan dan penyelenggaraan PAK pada Anak Usia Dini, standar PAUD menjadi acuan dalam pengembangan, implementasi, dan evaluasi kurikulumnya. Selain itu, Standar Tingkat Pencapaian Perkembangan Anak (STPPA) menjadi acuan untuk mengembangkan standar isi, proses, penilaian, pendidik dan tenaga kependidikan, sarana serta prasarana, pengelolaan dan pembiayaan. STPPA juga menjadi acuan dalam pengembangan kurikulum PAUD yang di dalamnya berisi tentang kriteria kemampuan yang dicapai anak pada seluruh aspek perkembangan dan pertumbuhan. Di dalamnya mencakup aspek nilai agama dan moral, fisik motorik, kognitif, bahasa, sosial emosional serta seni. Aspek-aspek tersebut menjadi bagian dari Kompetensi Dasar yang harus dicapai, yang dirumuskan dalam tujuan pembelajaran. ${ }^{5}$

\footnotetext{
${ }^{1}$ Kalis Stevanus, Menjadi Orangtua Bijak: Solusi Mendidik Dan Melindungi Anak Dari Pengaruh Pergaulan Buruk (Yogyakarta: Yayasan Pusataka Nusatama, 2016).42

${ }^{2}$ Jurnal Ilmiah Anak Usia Dini (Jakarta: Dirjen Pendidikan Luar Sekolah, 2003),8.

${ }^{3}$ PAUD : Investasi Masa Depan Bangsa (Jakarta: Direktorat Jenderal Pendidikan Luar Sekolah, 2006), iii.

${ }^{4}$ Dirjend PAUD-Dikmas, Kurikulum Pendidikan Anak Usia Dini, Apa, Mengapa Dan Bagaimana. (Jakarta: Jakarta: Dirjen PAUD-Dikmas, 2015), 1.

${ }^{5}$ Dirjend PAUD-Dikmas, Kurikulum Pendidikan Anak Usia Dini, Apa, Mengapa Dan Bagaimana, 8.
} 
Hal-hal tersebut sesuai mandat Kurikulum 2013 nomor 146 tahun 2014 dalam pasal 3 ayat (1) kurikulum PAUD disebut Kurikulum 2013 Pendidikan Anak Usia Dini. (2) Kurikulum 2013 Pendidikan Anak Usia Dini mengacu pada Standar Nasional Pendidikan Anak Usia Dini. Begitupun dalam pasal 5 ayat (1) Struktur Kurikulum PAUD menurut program-program pengembangan yang mencakup nilai agama dan moral, fisik motorik, kognitif, bahasa, sosial dan seni.

Guna mencapai tujuan pembelajaran PAK pada Anak usia Dini, diperlukan strategi pembelajaran yang tepat sesuai keadaan Anak Usia Dini sebagai upaya pengembangan anak-anak Kristen yang mencakup segala aspek, baik aspek spiritual dan moral, motorik, kognitif, bahasa, sosial emosional serta seni.

Dikatakan Evi Muafiah, bahwa masa usia dini merupakan masa peletak dasar atau fondasi awal bagi pertumbuhan dan perkembangan selanjutnya. Karena itu sangat penting memperhatikan pendidikan bagi anak di usia tersebut. ${ }^{6}$

Ditambahkan Ted Ward yang dikutip Sidjabat, bahwa kenyataannya sekitar 80\% pembentukan dan pengembangan kepribadian setiap individu telah dibentuk pada usia balita. ${ }^{7}$ Lebih lanjut dikatakan Stevanus, dalam perspektif Kristen, pembentukan karakter, watak dan moralitas anak tidak terpisahkan dari pertumbuhan imannya (spiritualitas). Bila sejak dini anak-anak Kristen sudah dibimbing untuk beriman kepada Tuhan Yesus, maka Roh Kudus mengerjakan pembaruan hidup di dalam diri anak. Sesungguhnya pembentukan karakter dan pertumbuhan iman tidak berjalan dengan sendirinya melainkan perlu diusahakan sedini mungkin. Anak-anak Kristen perlu dididik dalam ajaran dan nasihat Tuhan sejak dini sebagaimana dimandatkan oleh Alkitab (Ef 6:1-3). ${ }^{8}$ Karena itu, penting untuk memperhatikan pendidikan Anak Usia Dini. Pendidikan bagi Anak Usia Dini memegang peran yang sangat penting guna menjadi fondasi pendidikan di jenjang selanjutnya.

Strategi pembelajaran sangatlah penting sebagai sarana untuk melakukan proses pembelajaran agar tujuan pembelajaran menjadi efektif dan materi pembelajaran dapat diserap dengan baik oleh anak didik. Pembelajaran tidak akan efektif bila strategi pembelajarannya tidak cocok dengan keadaan peserta didiknya. Dengan demikian, pemilihan strategi pembelajaran yang tepat adalah suatu kemutlakan, termasuk Pendidikan Agama Kristen pada Anak Usia Dini.

\section{Metode Penelitian}

Artikel ini menggunakan pendekatan kualitatif deskriptif dengan menggunakan studi pustaka yaitu literatur yang relevan dengan pokok pembahasan. Artikel ini akan

\footnotetext{
${ }^{6}$ Evi Muafiah, "Strategi Pembelajaran Multiple Intelligences Di TK/RA Ponorogo", ThufuLA, Vol. 4, No. 1 (Desember 2016): 64. 1996), 206.

${ }^{7}$ B.S. Sidjabat, Strategi Pendidikan Kristen: Suatu Kajian Teologis-Filosofis (Yogyakarta: Andi Offset,

${ }^{8}$ Kalis Stevanus, Mendidik Anak (Yogyakarta: Lumela, 2018), 31.
} 
menguraikan konsep teoretis tentang landasan teologis Pendidikan Agama Kristen Anak Usia Dini, dan strategi pembelajaran untuk Anak Usia Dini dalam proses pembelajaran guna mengimplementasikan nilai-nilai kekristenan dapat diserap dengan baik dan optimal oleh peserta didik.

\section{Hasil dan Pembahasan}

\section{Landasan Teologis PAK Anak Usia Dini}

Seorang pendidik PAK pada Anak Usia Dini, diharapkan sebelum mengajar, dia telah memiliki fondasi pemahaman mengenai tugas yang diemban khususnya ditinjau dari perspektif iman Kristen atau Alkitab.

Pembelajaran Pendidikan Agama Kristen (PAK) adalah sebagai pendidikan iman Kristen yang landasannya, cara kerjanya serta misinya berakar dari nilai-nilai kristiani sebagaimana diajarkan dalam Alkitab. Pengajaran Agama Kristen memiliki landasan Alkitab baik di perjanjian Lama maupun Perjanjian Baru. Yang dimaksud dengan dasar Alkitabiah dari pembelajaran Pendidikan Agama Kristen (PAK) adalah landasan teologis. Pembelajaran Pendidikan Agama Kristen (PAK) yang Alkitabiah harus mendasarkan diri pada Alkitab sebagai Firman Tuhan dan menjadikan Kristus sebagai pusat berita atau pengajarannya serta bermuara pada hasilnya,yakni pembaruan rohani yang menghasilkan karakter Kristus.

Sidjabat secara mendalam menguraikan alasan mengapa mengajar sebagai landasan teologis dalam rangka meningkatkan kualitas layanannya demi peningkatan mutu hidup peserta didiknya. Pertama, Allah sebagai Pengajar. Alkitab sebagai sumber bagi dasar dan prinsip hidup kristiani menjelaskan bahwa di dalam membimbing manusia untuk lebih mengenal Allah, Ia berperan sebagai pengajar. Sebagai pengajar, Ia aktif memberitahukan kebenaran. Kebenaran itu adalah pribadi-Nya, firman-Nya bahkan perbuatan-Nya. Ditandaskan Sidjabat, perbuatan mengajar itu telah dimulai-Nya di Taman Eden, dengan manusia pertama yaitu Adam dan Hawa, agar mereka hidup memuliakan Dia dalam segala aspek hidup. Allah sudah dan sedang berkomunikasi kepada manusia dengan pelbagai cara di sepanjang sejarah (bdk.Ibr.1:1-2). Sepanjang perjalanan sejarah bangsa Israel, Allah menampilkan diri-Nya sebagai pengajar. Allah memilih pemimpin seperti Musa, Harun, Miriam, Yosua, dan Kaleb. Allah telah berbicara kepada mereka dan apa yang diajarkan itu selanjutnya mereka sampaikan kepada umat. Setelah bangsa Israel masuk tanah Kanaan, Allah mengangkat para hakim sebagai pengajar umat. Selain itu, Allah juga menetapkan para imam sebagai pelayan. Mereka mengajar bagaimana umat harus berbakti dengan benar kepada Allah dan memuliakan Dia dalam segala segi hidup mereka. Bahkan tak kalah penting lagi ialah Allah menghadirkan nabi untuk menyampaikan kehendak-Nya, misalnya yang berkaitan dengan keadilan, penghakiman, penghukuman, dan kebenaran. Di samping para nabi, juga Allah membangkitkan para ahli Taurat dan orang bijaksana. Mereka tampil untuk memberi pengajaran kepada umat Allah. 
Kedua, teladan Tuhan Yesus, Sang Guru. Tugas mengajar sangat penting sebagaimana dipahami dari kehidupan dan pelayanan Tuhan Yesus sendiri. Dia datang ke dunia telah memperkenalkan Allah kepada manusia melalui kegiatan mengajar, berkhotbah, mengadakan mujizat dan menunjukkan teladan hidup yang sempurna. Di dalam kitab Injil, Tuhan Yesus dikenal sebagai "guru yang datang dari Allah" (Yoh.3:2) Dan Tuhan Yesus sendiri dengan tegas mengakui diri-Nya sebagai "Guru" kepada para murid-Nya (Yoh.13:13). Dikatakan Sidjabat, pengajaran Tuhan Yesus bertujuan untuk memperkenalkan Allah, sifat dan perbuatan-Nya kepada manusia (Yoh.1:14,18; 14:6). Ia juga menjelaskan siapa diri-Nya, asal, tujuan hidup serta pekerjaan-Nya yang sangat utama (Yoh.8:42,58; 16:28). Dan tema sentral pengajaran Tuhan Yesus adalah Kerajaan Allah (Mat.5-7).

Ketiga, para rasul sebagai pengajar. Tuhan Yesus memilih dan mempersiapkan para murid-Nya menjadi pengajar dan pemberita Injil Kerajaan Allah. Sebelum meninggalkan para murid untuk kembali ke surga, Tuhan Yesus memberikan mandat penting bagi mereka, yakni menjadikan semua suku bangsa menjadi jurid-Nya (Mat.28:19-20).

Keempat, setelah Hari Pentakosta, Roh Kudus turun ke dunia, gereja terbentuk. Setelah orang bertobat dan percaya kepada Tuhan Yesus, para rasul melaksanakan tugas mengajar sebagaimana dimandatkan Tuhan Yesus (Kis.2:42). Mereka mengajar tentang siapa dan apa yang dilakukan Tuhan Yesus terhadap orang-orang yang belum percaya (Kis.4:2,18). Meskipun mereka menghadapi tantangan dari pihak tokoh agama Yahudi, para rasul tetap bertekun di dalam tugas mengajar (Kis.5:21,25,42). Gereja di Yerusalem memusatkan pengajarannya kepada pemberitaan Tuhan Yesus yang mati, bangkit dan hidup selamanya.

Kelima, ada karunia mengajar dalam gereja (Ef. 4:11-13). Anggota jemaat sebagai pengajar. Paulus meminta Timotius agar memilih anggota jemaat yang memiliki karunia mengajar (1 Tim.3:2; 2 Tim.2:24). Paulus meminta agar jemaat untuk terus menerus bertekun dalam pengajaran para rasul (2 Tes.2:15; Kol.2:7). ${ }^{9}$

Dari apa yang diuraikan Sidjabat di atas, dapat dikatakan bahwa gereja memiliki kedudukan yang penting. Menurut Dien Sumiyatiningsih, gereja berperan penting sebagai wadah pembaruan umat, memelihara mereka serta menjaga mereka agar tetap kudus, dan tak bercacat di hadapan Allah (Ef.5:25-26). Karena itu, gereja harus menajalankan fungsinya bukan hanya sebagai persekutuan ibadah, tetapi juga sebagai persekutuan yang belajar-mengajar. Gereja menyediakan kesempatan belajar bagi umat dari segala kategori usia. ${ }^{10}$

9 B.S Sidjabat, Menjadi Guru Profesional : Sebuah Perspektif Kristiani (Yogyakarta: Andi Offset, 2000), 12-13,19-25.

${ }^{10}$ Dien Sumiyatiningsih, Mengajar Dengan Kreatif Dan Menarik: Buku Pegangan Untuk Mengajar Pendidikan Agama Kristen (Yogjakarta: Andi Offset, 2007), 27-28. 
Juga dikatakan Ismail, ada dugaan kuat, kegiatan utama di gereja-gereja yang mulamula ini adalah belajar seperti tertulis dalam Galatia 6:6 pertemuan itu disebut "pengajaran dalam Firman" (bdk. Fil.1:14). Yang mengajar adalah keduabelas murid. Dalam perkembangan waktu muncullah jabatan "guru" pertama disebut di gereja Antiokhia (Kis.13:1) di mana para pengikut Tuhan Yesus disebut Kristen (Kis.11:26). Menurut Ismail, bukan berarti umat hanya menjadi penerima. Umat juga mengajar, mereka saling mengajar seperti tertulis di Tesalonika 5:11,"nasihatilah seorang akan yang lain dan saling membangunlah kamu seperti yang memang kamu lakukan." Di rumah pun pendidikan berlangsung, di mana orangtua sebagai pengajar yang mendidik anak (Ef.6:4). Menjelang kenaikan-Nya Tuhan Yesus berpesan agar pengikut-Nya mengajar dan belajar (Mat.28:19-20). Gereja yang mula-mula menanggapi pesan itu,"Mereka bertekun dalam pengajaran..." (Kis.2:42). ${ }^{11}$

Sangat jelas bahwa mandat untuk mengajar umat sudah dimulai sejak Perjanjian Lama. Umat telah menerima pendidikan baik dalam konteks keluarga maupun umat Allah. Kemudian, di Perjanjian Baru, hal mengajar telah dimulai oleh Tuhan Yesus ketika memanggil para murid-Nya yang menjadi cikal bakal gereja. Tuhan Yesus mendidik mereka agar nanti mereka menjadi pendidik untuk memuridkan orang lain menjadi murid-Nya. Jelas di dalam Matius 28:19-20 setiap warga gereja dipanggil melakukan tugas untuk menjadikan semua bangsa murid Kristus. Paulus menjelaskan tujuan dari pemuridan atau pendidikan warga gereja itu adalah adanya proses menuju pertumbuhan dan kedewasaan iman dalam Kristus (Ef. 4:11-16).

\section{Pendidikan Agama Kristen Pada Anak di Perjanjian Lama}

Pendidikan Agama Kristen (PAK) tidak terlepas dari Pendidikan Agama umat Yahudi. Pendidikan Agama Kristen (PAK) itu dimulai dengan terpanggilnya Abrahan menjadi nenek moyang umat pilihan Tuhan, bahkan Pendidikan Agama Kristen (PAK) berpangkal kepada Tuhan sendiri karena Tuhan yang menjadi Pendidik Agung bagi umat-Nya.

Tuhan berjanji kepada Abraham bahwa keturunannya akan menjadi bangsa yang besar. Demikian janji Tuhan kepada Abraham:

"Aku akan membuat engkau menjadi bangsa yang besar, dan memberkati engkau serta membuat namamu masyur; dan engkau akan menjadi berkat. Aku memberkati orang-orang yang memberkati engkau, dan mengutuk orang-orang yang mengutuk engkau dan olehmu semua kaum di bumi akan mendapat berkat" (Kej 12:2-3).

Nenek moyang umat Yahudi, Abraham, Ishak dan Yakub menjadi guru (pendidik) bagi seluruh keluarganya. Sebagai bapak-bapak dari bangsanya, mereka bukan saja menjadi imam yang merupakan pengantara antara Tuhan dengan umat-Nya, tetapi juga

\footnotetext{
${ }^{11}$ Andar Ismail, Selamat Menabur (Jakarta: BPK Gunung Mulia, 2017), 90.
} 
menjadi guru yang mengajarkan tentang perbuatan-perbuatan Tuhan yang agung itu dengan segala janji-Nya yang membawa berkat kepada umat Yahudi sebagai umat pilihan Tuhan turun temurun.

Ishak meneruskan pengajaran yang diterimanya dari ayahnya Abraham dan kemudian anaknya Yakub juga menanamkan segala pengajaran Tuhan tersebut kepada anak-anaknya sehingga pengetahuan tentang janji-janji Tuhan dan berkatnya tetap terpelihara oleh umat Tuhan, bangsa Israel.

Musa dipilih Tuhan untuk membebaskan umat-Nya dari penindasan. Musalah yang diangkat menjadi panglima dan pemimpinnya tetapi juga menjadi guru dan pemberi hokum-hukum bagi mereka. Musa mendidik mereka di padang gurun dan mengatur pendidikan itu agar pengajaran Firman Tuhan yang memberi dasar seluruh kehidupan umat Tuhan itu akan dilanjutkan oleh pengganti-penggantinya kemudian.

Tiap-tiap keturunan orang Israel menyampaikan segala pengajaran Tuhan tersebut kepada keturunan yang berikutnya. Proses ini berlangsung terus dari generasi ke generasi selanjutnya. Hal ini nyata telah dituliskan Musa di Perjanjian Lama, di kitab Ulangan 6:4-9

"Dengarlah, hai Israel: Tuhan itu Allah kita, TUHAN itu Esa! Kasihilah TUHAN, Allahmu, dengan segenap hatimu dan dengan segenap jiwamu dan dengan segenap kekuatanmu. Apa yang kuperintahkan kepadamu pada hari nini haruslah engkau perhatikan, haruslah engkau mengajarkannya berulang-ulang kepada anakanakmu dan membicarakannya apabila engkau duduk di rumahmu, apabila engkau sedang dalam perjalanan, apabila engkau berbaring dan apabila engkau bangun.Haruslah juga engkau mengikatkannya sebagai tanda pada lenganmu dan haruslah engkau menuliskannya pada tiang pintu rumahmu dan pada tiang pintu gerbangmu" (Ul 6:4-9).

Kitab Ulangan pada umumnya memiliki tujuan utama dari pidato-pidato Musa adalah untuk meyakinkan bangsa Israel sebagai umat Tuhan sebelum ia menyerahkan tampuk kepemimpinan kepada Yosua dan bangsa itu berjuang melawan orang Kanaan. Secara keseluruhan kitab Ulangan mengajarkan isi dan arti dari agama Israel, menantang mereka untuk melaksanakan hukum-hukum Tuhan yang disampaikan melalui Musa. Tuhan meminta dari umat Tuhan untuk memiliki ketaatan mutlak dalam segala bidang (Ul.11:1). Selain itu khususnya Ulangan 6:4-9 membahas mengenai pentingnya pendidikan agama sehingga dalam keluarga para orang tua diperintahkan untuk memberi pendidikan agama bagi anak-anak sejak masa kanak-kanak.

Menurut konteks Ulangan 6:4-9 adalah pola pendidikan orang tua bagi anak-anak mereka. ${ }^{12} \mathrm{Hal}$ itu juga diteguhkan oleh Sidjabat sebagai berikut:

"Pendidikan anak mengenai iman dan budi pekerti dalam Perjanjian Lama khususnya Ulangan 6:4-9 merupakan tanggung jawab orang tua dalam keluarga.

${ }^{12}$ John Balchin, Intisari Alkitab Perjanjian Lama (Jakarta: Persekutuan Pembaca Alkitab, 2008),47 
Keluarga menjadi agen pendidikan iman dan budi pekerti bagi anak-anak mereka"13

Dalam Ulangan 6:6-9 Tuhan menyatakan kepada orang tua agar mereka belajar mengenal Dia dengan sungguh-sungguh dalam kasih dan kesetiaan.

"Apa yang kuperintahkan kepadamu pada hari ini haruslah engkau perhatikan, haruslah engkau mengajarkannya berulang-ulang kepada anak-anakmu dan membicarakannya apabila engkau duduk di rumahmu, apabila engkau sedang dalam perjalanan, apabila engkau berbaring dan apabila engkau bangun".

Secara teologis jelas ayat ini memerintahkan bahwa anak-anak agar diajarkan tentang takut akan Allah sejak dini. Allah menghendaki agar keluarga menjadi wadah untuk mengajarkan anak-anak takut akan Dia melalui pengajaran Pendidikan Agama Kristen. Ditambahkan Sidjabat sebagai berikut:

"Dalam terang kehendak Allah, keluarga terpangggil untuk menjadi tempat saluran kasih dan berkat Allah dan menjadi wadah bagi transmisi nilai-nilai kekristenan. Mengajar anak-anak untuk mengenal dan takut akan Allah adalah tugas imperative (mendesak)"14

Pendidikan anak pada umumnya menyatakan bahwa lingkungan dan agen yang paling banyak mempengaruhi pembentukan karakter, iman dan nilai-nilai adalah keluarga intil. Keluarga merupakan lingkungan primer dalam pembentukan anak sejak dini. Sebelum anak menerima pengaruh dari teman sebaya maupun guru di sekolah atau di gereja, ia sudah lebih dulu dibentuk ibu dan ayahnya serta dipengaruhi saudara maupun pengasuhnya. Dengan kata lain, bagi anak, keluarga inti dianggap sangat berharga.

John Balchin menerangkan fungsi keluarga inti (nuclear family) sebagai berikut: pertama, keluarga sebagai fungsi prokreasi. Fungsi prokreasi adalah keluarga menghasilkan keturunan dan membesarkan anak-anak mereka secara bijak. Kedua, keluarga sebagai fungsi edukasi. Fungsi edukasi di dalam keluarga adalah membantu anak untuk belajar banyak hal termasuk nilai-nilai, sikap-sikap, pengetahuan dan sebagainya. Ketiga, keluarga sebagai fungsi religious. Fungsi religius di keluarga yakni pengembangan nilai iman (agama). Konsep mengenai Tuhan pada diri anak sebenarnya bertumbuh dan berkembang dari kualitas pemeliharaan orang tua yang dialaminya. Anak menyaksikan pengalamannya dengan orang tua dalam memahami Tuhan. ${ }^{15}$

Orang tua yang rajin berdoa, tekun membaca Kitab Suci dan giat bekerja tetapi tetap memperhatikan anak, lambat laun ia belajar bahwa nilai religius dalam arti takut akan Tuhan itu sangat penting. Bekerja dan berdoa serta beribadah dianggap panggilan

\footnotetext{
${ }^{13}$ B.Samuel Sidjabat, Membesarkan Anak Dengan Kreatif (Yogjakarta: Andi Offset, 2008).17

${ }^{14}$ Ibid.139

${ }^{15}$ Balchin, Intisari Alkitab Perjanjian Lama.38
} 
hidup orang beriman dalam memuliakan Tuhan. Anak belajar tentang makna keseimbangan di dalam hidup. Di dalam sanubarinya juga anak akan belajar mengadopsi nilai-nilai religius itu yang berguna bagi kehidupan masa depannya. ${ }^{16}$

Untuk mendidik anak, orang tua diijinkan menggunakan "tongkat didikan" kepada anak-anaknya dalam menuntun mereka beriman kepada Allah. "Siapa tidak menggunakan tongkat, benci kepada anaknya; tetapi siapa mengasihi anaknya menghajar dia pada waktunya" (Amsal 13:24). Artinya ayat ini, bahwa ada cara yang unik bagi setiap anak di dalam mendidiknya melalui pengajaran pengajaran Pendidikan Agama Kristen. (PAK) sejak masih kanak-kanak. Hal itu perlu mendapat perhatian bagi guru Pendidikan Agama Kristen (PAK) dan khususnya orang tua Kristen di keluarga,

Selain perintah Musa di dalam kitab Ulangan 6:4-7, juga ada tercatat perintah yang serupa di dalam Amsal 22 : 6 yang secara khusus diberikan kepada orang tua agar mereka mendidik anak-anak mereka. Tuhan menghendaki supaya anak-anak sejak dini dididik di dalam jalan-Nya. Pemazmur mengatakan di dalam Mazmur 127:3 menunjukkan betapa berharganya anak-anak di hadapan Tuhan. Sebab mereka adalah milik pusaka Tuhan sehingga orang tua bertanggung jawab mendidik mereka.

\section{Pendidikan Agama Kristen Pada Anak di Perjanjian Baru}

Kitab Injil memberi informasi bahwa Tuhan Yesuspun mempedulikan pembentukan karakter dan iman anak-anak kecil. Ketika sejumlah orang tua membawa anak-anak mereka kepada Tuhan Yesus, Dia menyambut dan menumpangkan tangan memberkati mereka (Mrk 10:13-16).

"Lalu orang membawa anak-anak kecil kepada Yesus, supaya Ia menjamah mereka; akan tetapi murid-murid-Nya memarahi orang-orang itu. Ketika Yesus melihat hal itu, Ia marah dan berkata kepada mereka:'Biarlah anak-anak itu datang kepadaKu, jangan menghalang-halangi mereka, sebab orang-orang seperti itulah yang empunya Kerajaan Allah. Aku berkata kepadamu: Sesungguhnya berangsiapa tidak menyambut Kerajaan Allah seperti seorang anak kecil, ia tidak akan masuk ke dalamnya'. Lalu Ia memeluk anak-anak itu dan sambil meletakan tangan-Nya atas mereka Ia memberkati mereka"

Sebelumnya, murid-muird melarang orang tua itu dan mencegah mereka membawa anak-anak mereka kepada Tuhan Yesus Sang Guru Agung. Namun sebaliknya Tuhan Yesus menegaskan supaya anak-anak jangan dihalangi untuk datang kepada-Nya. Dikatakan: "Biarkanlah anak-anak itu, jangan menghalang-halangi mereka datang kepadaKu, sebab orang-orang seperti itulah yang empunya Kerajaan Sorga". Sidjabat

\footnotetext{
${ }^{16}$ Ibid. 35
} 
menjelaskan istilah Yunani kata "anak-anak" itu adalah ta paidia yang memiliki arti bayi atau anak-anak sekitar usia enam tahun pertama. ${ }^{17}$

Juga diperingatkan oleh Tuhan Yesus agar orang dewasa memperhatikan betapa seriusnya tantangan yang dihadapi oleh anak-anak, yaitu penyesatan dari dunia dan lingkungannya. Diakui oleh Tuhan Yesus bahwa dunia ini sarat dengan upaya membawa anak-anak yang telah percaya menjauhi Dia.

Sebagaimana diungkapkan Paulus bahwa tradisi mendidik anak-anak secara ketat juga terus berlangsung ketika masa para rasul masih hidup (1Tim.3:15), dan juga di dalam Gereja perdana. Walaupun tempatnya tidak lagi dipusatkan di Sinagoge, berangsung-angsur dialihkan atau dipusatkan ke dalam gereja lokal, tempat orangorang percaya bersekutu.

Paulus juga menuliskan hal yang serupa tentang pentingnya pendidikan iman bagi anak-anak sejak dini:

"Hai anak-anak, taatilah orang tuamu di dalam Tuhan, karena haruslah demikian. Hormatilah ayahmu dan ibumu-ini adalah suatu perintah yang penting, seperti yang nyata dari janji ini : supaya kamu berbahagia dan panjang umurmu. Dan kamu, bapa-bapa, janganlah bangkitkan amarah di dalam hati anak-anakmu, tetapi didiklah mereka di dalam ajaran dan nasihat Tuhan" (Ef 6:1-4).

Berdasarkan uraian dari sisi Alkitab baik Perjanjian Lama maupun Perjanjian Baru, tak dapat disangkal, gereja bertangggung jawab mengajar atau mendidik umatnya, menjadi wadah di mana iman itu bisa bertumbuh. Tanpa tugas pendidikan tersebut, tidak mungkin gereja berkembang seperti dikehendaki Tuhan Yesus, apalagi dapat mengalami pertumbuhan iman. Pendidikan Agama Kristen (PAK) merupakan hal yang sangat penting dalam kehidupan gereja. Gereja tidak boleh hanya mengandalkan PAK di sekolah. Gereja harus sibuk mengajar-mendidik umatnya dimulai dari kelompok Anak Usia Dini di gereja. Gereja bertanggung jawab memberikan pelayanan Pendidikan Agama Kristen (PAK), yakni pemuridan bagi warganya sejak usia dini. Dengan kata lain, gereja perlu melaksanakan PAK dalam program pembinaan gereja secara profesional.

\section{Strategi Pembelajaran Pendidikan Agama Kristen Pada Anak Usia Dini}

Kata strategi berasal dari bahasa Latin strategia, yang diartikan sebagai seni penggunaan rencana untuk mencapai tujuan. Jika dikaitkan dengan pembelajaran, maka strategi pembelajaran dapat diartikan sebagai pola kegiatan pembelajaran yang diplih dan digunakan secara kontekstual, sesuai dengan karakteristik peserta didik, kondisi sekolah, lingkungan sekitar serta tujuan khusus pembelajaran yang dirumuskan. Ditandaskan oleh Prof. Sri Anitah W, bahwa di dalam strategi pembelajaran terdiri dari metode dan teknik (prosedur) yang akan menjamin bahwa peserta didik akan benarbenar mencapai tujuan pembelajaran. ${ }^{18}$ Ini juga dikatakan Evelin Siregar dan Hartini

\footnotetext{
${ }^{17}$ Sidjabat, Membesarkan Anak Dengan Kreatif. 92

${ }^{18}$ Sri Anitah W, Strategi Pembelajaran, 2020, diakses 28 Juni 2020.
} 
Nara bahwa strategi pembelajaran adalah suatu rencana untuk mencapai tujuan. Strategi pembelajaran terdiri dari metode, teknik, prosedur yang akan menjamin peserta didik dapat mencapai tujuan aakhir kegiatan pembelajaran. ${ }^{19}$ Pendapat yang sama diungkapkan oleh Hamruni mengartikan strategi pembelajaran adalah upaya untuk mewujudkan proses pembelajaran mencapai tujuan yang telah ditetapkan, yakni untuk menguasai kompetensi yang diharapkan. ${ }^{20}$

Dari uraikan di atas, penulis menyimpulkan yang dimaksud strategi pembelajaran adalah suatu rencana untuk mencapai tujuan pembelajaran, yaitu materi pembelajaran dapat disampaikan dengan efektif dan dapat diserap dengan baik oleh peserta didik.

Pembelajaran Pendidikan Agama Kristen (PAK) merupakan salah satu pendidikan pra sekolah yang bertujuan untuk membawa anak memiliki pendirian iman yang kuat. Pembelajaran Pendidikan Agama Kristen (PAK) pada Anak Usia Dini menuntut strategi pembelajaran yang cocok dengan keberadaan Anak Usia Dini. Guru PAK yang tidak memahami bagaimana memilih strategi pembelajaran yang relevan, cocok dengan keberadaan Anak Usia Dini dalam mengelola pembelajaran PAK akan menghambat pelaksanaan proses pembelajaran sehingga tidak tercapai tujuan PAK bagi Anak Usia Dini.

Strategi pembelajaran PAK secara umum adalah pola strategis yang berisi langkahlangkah prosedur dalam merancang program pembelajaran PAK sesuai tuntutan kurikulum untuk memperoleh hasil belajar peserta didik. ${ }^{21}$ Dalam kurikulum PAK bermuatan ranah afektif dan psikomotorik lebih besar daripada kognitif sehingga melalui pembelajaran PAK diharapan anak didik mengalami perkembangan iman serta moralnya selain perkembangan pengetahuannya dan psikomotoriknya. Keutuhan perkembangan ranah afektif, kognitif, psikomotorik didasarkan pada nilai-nilai kristiani. $^{22}$

Perlu juga dipahami bahwa strategi pembelajaran untuk Anak Usia Dini memang berbeda dengan yang diperuntukkan untuk peserta didik jenjang pendidikan yang lebih tinggi. Hamdani menyatakan berbeda dikarenakan Anak Usia Dini sedang dalam proses pertumbuhan yang belum maksimal baik secara fisik, kognitif, psikomotor maupun secara psikologis. Anak Usia Dini adalah masa perkembangan dan pertumbuhan anak yang memerlukan gizi seimbang serta stimulasi yang intensif. Masa ini disebut sebagai usia emas (golden age) dengan sifat mudah menerima segala rangsangan yang masuk ke dalam dirinya dan menggenggam erat apa yang sudah diterima. ${ }^{23}$ Elisabeth mengatakan

78

${ }^{19}$ Eveline Siregar dan Hartini Nara, Teori Belajar dan Pembelajaran (Bogor: Ghalia Indonesia, 2011),

${ }^{20}$ Hamruni., Strategi Pembelajaran (Yogyakarta: Insan Madani, 2012).

${ }^{21}$ Oditha R. Hutabarat, Model-Model Pembelajaran Aktif Pendidikan Agama Kristen SD, SMP, SMA Berbasis Komptensi (Bandung: Bina Media Informasi, 2005),35.

22 Oditha R. Hutabarat dan Janse Belandina Non-Serrano, Pedoman Untuk Guru PAK (Bandung: Bina Media Informasi, 2006), 43.

${ }^{23}$ Hamdani, Strategi Belajar Mengajar (Bandung: Pustaka Setia, 2011),7. 
pada usia ini anak-anak sudah dapat mengami dan mengerti nilai-nilai iman iman. Masa anak di usia dini ini benar-benar merupakan masa yang teoat untuk meletakkan fondasi bagi pembentukan keprbadian secara utuh sehingga mereka memiliki kesiapan dalam memasuki pendidikan lebih lanjut. ${ }^{24}$

Pada esensinya, pengelolaan pembelajaran yang baik merupakan suatu hal mutlak yang harus dilakukan oleh guru PAUD agar dapat menstimulasi tumbuh kembang anak didik dengan optimal optimal. Untuk mampu mengelola pembelajaran yang baik tersebut, maka guru PAUD dituntut memiliki kompetensi yang baik. ${ }^{25}$ Dan salah satu kompetensi tersebut adalah bagaimana memilih dan menggunakan strategi pembelajaran yang cocok dengan keberadaan anak didik, yakni Anak Usia Dini. Pembelajaran pada Anak Usia Dini dapat dioptimalkan perkembangannya, maka dibutuhkan strategi pembelajaran secara khusus. Strategi pembelajaran secara khusus itu adalah sebuah pola atau model pembelajaran yang dapat diterima oleh Anak Usia Dini.

Berikut ada empat strategi pembelajaran yang dapat diimplemenatsi guru PAK untuk pembelajaran Agama Kristen pada Anak Usia Dini:

\section{Strategi Pembelajaran Edutaintment}

Strategi pembelajaran edutainment adalah suatu proses pembelajaran yang dikemas dengan konsep hiburan sehingga peserta didik tidak menyadari bahwa mereka sebenarnya sedang belajar. ${ }^{26}$ Jadi sebenarnya konsep pembelajaran edutainment adalah memadukan atau mensinergikan antara education dan entertainment yang dimaksudkan agar proses pembelajaran berlangsung menyenangkan, bukan menegangkan atau pun menakutkan bagi peserta didik.

Strategi pembelajaran ini dapat digunakan pada PAK Anak Usia Dini sebab proses pembelajarannya menyenangkan, menggembirakan dan menarik perhatian anak didik sehingga materi pelajaran dapat disampaikan dengan baik dan dengan mudah diserap oleh peserta didik.

Strategi pembelajaran ini dapat dikemas dalam berbagai bentuk, yaitu: metode bermain, metode bercerita, metode bermain peran, metode beryanyi, karya wisata, serta aktivitas yang praktek langsung (misalnya pemanfaatan komputer, mengadakan proyek). Tanpa disadari oleh anak-anak, sebenarnya mereka sedang belajar.

\section{Strategi Pembelajaran Ekspositori}

Strategi pembelajaran ini berlangsung searah, yaitu menekankan pada proses penyampaian materi secara verbal dari guru kepada peserta didik. Misalnya metode

\footnotetext{
${ }^{24}$ Elisabeth, Pembelajaran PAK (Pendidikan Agama Kristen) Pada Anak Usia Dini, (Bandung: Bina Media Informasi, 2009),2.

${ }^{25}$ Mirawati, dkk, "PPBK: Peningkatan Kemampuan Guru Paud Dalam Pengelolaan Pembelajaran Bagi Anak Usia Dini," JURNAL ABDIMAS UMTAS, Vol. 2, No. 1 (2019): 92.

${ }^{26}$ Aip Saripudin, "Strategi Edutainment Dalam Pembelajaran Di PAUD (Studi Kasus Pada TK Di Kota Cirebon)," AWLADY: Jurnal Pendidikan Anak Vol. 4, No.1 (Maret 2018): 131.
} 
yang sering dipakai dalam strategi ini adalah pertanyaan didaktik, praktek dan latihan serta demonstrasi. Strategi ini sangat berpusat pada guru dan paling sering digunakan pada PAUD. Strategi ini menekankan penyampaian materi sebagai fokus utama, agar materi diserap secara optimal oleh peserta didik. Strategi ini efektif untuk menentukan informasi atau membangun keterampilan tahap demi tahap. Di satu sisi srategi ini mudah untuk digunakan dan direncanakan, namun kurang dalam mengembangkan kemampuan-kemampuan, proses-proses dan sikap yang diperlukan untuk pemikiran kritis dan hubungan interpersonal serta belajar kelompok.

Strategi ini sangat penting, mengingat kondisi anak yang memerlukan banyak pengetahuan, bimbingan, arahan dalam proses pembelajaran. Sehingga guru yang menjadi ujung tombak dalam proses belajar anak. Berikut ini beberapa metode yang menjadi bagian strategi pembelajaran ekspositori. Undangan atau ajakan berfungsi sebagai cara untuk menggiring anak-anak agar mereka menggunakan kesempatan diberikan guru untuk melakukan eksplorasi, atau interaksi dengan teman-teman lain dan guru. Contohnya "anak-anak mari sini, mari kita perhatikan gambar ini". Dengan undangan verbal seperti itu anak-anak akan terundang untuk melakukan kegiatan. Semakin sering ajakan dilakukan sama dengan semakin banyak memberi kesempatan anak untuk mengambil bagian dalam berbagai kegiatan. Masitoh menyatakan metode Do-it-signal adalah arahan sederhana yang diberikan kepada anak agar dia mau melakukan sesuatu tindakan, atau ajakan kepada anak-anak mereka agar melakukan sesuatu. ${ }^{27}$ Misalnya, "ayo tunjukkan kalau kamu bisa bernyanyi". Jenis-jenis pernyataan positif ini juga menambah kejelasan bagi anak tentang apa yang harus ia lakukan. Do-itsignal bisa dilakukan bersamaan dengan undangan atau saling bergantian dan mendorong anak untuk lebih berani atau bisa mengatasi rasa malu.

\section{Strategi Pembelajaran Berbasis Masalah}

Strategi ini bisa diartikan sebagai rangkaian aktivitas pembelajaran yang menekankan pada proses penyelesaian masalah yang dihadapi secara ilmiah. Bagi Anak Usia Dini masalah yang dimaksudkan adalah masalah sederhana yang ditemui setiap hari, di rumah, di sekolah, maupun dalam bersosialisasi. Secara khusus dalam PAK selalu diarahkan dalam pengenalan akan Tuhan, kasih, doa dan penyelesaian masalah secara Kristiani sebagai penyeimbang penyelesaian secara ilmiah. Guru PAK dalam pembelajaran ini adalah menjabarkan suatu tugas tertentu menjadi bagian-bagian yang lebih rinci atau khusus dan operasional sehingga mudah dipahami dan dilaksanakan oleh anak-anak. Misalnya, guru mengharapkan anak dapat beribadah bersama, maka guru terlebih dahulu harus mengajarkan tugas pendukungnya misalnya menyiapkan Alkitab untuk setiap anak, memilih anak yang membawa persembahan, menentukan beberapa anak yang bertugas berdoa, dan memilih satu anak untuk membaca Alkitab,

\footnotetext{
${ }^{27}$ Masitoh, Strategi Pembelajaran TK (Jakarta: Universitas Terbuka, 2005), 7-8.
} 
dan sebagainya. Guru membimbing anak mulai dari tugas yang termudah kemudian menambah tingkat kesulitannya.

\section{Strategi Pembelajaran melalui Mendongeng}

Mendongeng merupakan suatu aktivitas yang sering digunakan dalam pembelajaran Anak Usia Dini. Menurut Kusmiadi, Sriwahyuningsih, dan Nurfalah, strategi pembelajaran melalui dongeng mudah dilakukan pendidik di mana saja, kapan saja bahkan tanpa bergantung ada atau tidaknya media. ${ }^{28}$

Metode mendongeng ialah metode yang mengisahkan suatu peristiwa atau kejadian kepada peserta didik. Kejadian atau peristiwa tersebut disampaikan kepada peserta didik melalui tutur kata, ungkapan dan mimik wajah yang unik. Metode ini dapat dilakukan dengan berbagai cara di antaranya adalah pertama guru menyampaikan cerita di hadapan anak secara langsung, kedua mendengarkan anak menceritakan pengalamannya, dan ketiga mengunakan media sebagai sarana dalam menyampaikan cerita. ${ }^{29}$ Menurut Burn sebagaimana dikutip Kusmiadi dan kawan-kawan, dongeng sangat bermanfaat untuk mengaktifkan berbagai aspek baik kognitif/intelektual, kepekaan, kehalusan budi, emosi, seni, fantasi, dan imajinasi bagi peserta didik. Selain itu, dongeng juga memiliki fungsi menghibur, mendidik, menggugah emosi, imajinasi, kreativitas, menumbuhkan sikap-sikap positif, mengembangkan kemampuan berbahasa, dan menambah perbendaharaan kosa kata bagi peserta didik. ${ }^{30}$

Bagi Anak Usia Dini mendengarkan dongeng atau cerita yang menarik dan dekat dengan lingkungannya merupakan kegiatan yang mengasyikkan. Sebenarnya mendongeng atau bercerita adalah metode yang sudah lama digunakan oleh gereja untuk melayani anak-anak tentang berbagai kisah di Alkitab. Guru dapat memanfaatkan metode mendongeng untuk mengaplikasikan PAK tentang nilai-nilai kristiani, pembentukan karakter Kristus kepada peserta didik. Selain itu, melalui mendongeng memberikan pengalaman belajar untuk mendengarkan, yaitu peserta didik dimungkinkan untuk mengembangkan kemampuan kognitif secara khusus kemampuan berfantasi yang menumbuhkan kreatifitas, afektif, dan psikomotorik.

\section{Kesimpulan}

Strategi pembelajaran yang diterapkan oleh guru PAUD-PAAK tergantung pada pendekatan yang digunakannya. Pemilihan dan penggunaan strategi pembelajaran yang tepat dengan keadaan atau karakteristik Anak Usia Dini akan berdampak positif dan optimal terhadap perkembangan kemampuan dan kecerdasan Anak Usia Dini. Strategi pembelajaran juga memberikan berbagai variasi dalam proses membentuk habituasi

28 Yuyun Nurfalah, Ade Kusmiadi, Sriwahyuningsih, "Strategi Pembelajaran Melalui Metode Dongeng Bagi Pendidik PAUD,” Jurnal Ilmiah Visi PTK-PNF Vol.3, no. 2 (2008): 198.

${ }^{29}$ Windisyahputra, Menghadirkan Lembaga PAUD Ideal (Takengon: Media Utama, 2014), 161.

${ }^{30}$ Ade Kusmiadi, Sriwahyuningsih, "Strategi Pembelajaran Melalui Metode Dongeng Bagi Pendidik PAUD.", 199 
atau pembiasaan yang baik bagi anak usia dini. Sehingga walaupun kegiatan dilakukan setiap hari anak tetap merasa tertarik, menikmati dan tidak cepat bosan. Karena itu, seorang guru PAK dapat memilih dan menerapkan strategi pembelajaran yang harus dilakukan agar proses pembelajaran dalam mengaplikasikan nilai-nilai kristiani sesuai Kurikulum Anak Usia Dini dapat tercapai secara efektif dan efisien, antara lain: pertama adalah strategi pembelajaran edutaintment, kedua: strategi pembelajaran ekspositori; ketiga: strategi pembelajaran berbasis masalah dan keempat: strategi pembelajaran melalui mendongeng. Semua strategi pembelajaran tersebut tidak ada yang lebih unggul antara metode yang satu dengan metode lainnya. Namun, dapat menjadi alternatif yang variatif dalam mengajarkan Agama Kristen untuk Anak Usia Dini.

\section{Referensi}

Ade Kusmiadi, Sriwahyuningsih, dan Yuyun Nurfalah. "Strategi Pembelajaran Melalui Metode Dongeng Bagi Pendidik PAUD." Jurnal Ilmiah Visi PTK-PNF Vol.3, no. 2 (2008).

Balchin, John. Intisari Alkitab Perjanjian Lama. Jakarta: Persekutuan Pembaca Alkitab, 2008.

Dkk, Mirawati. “PPBK: Peningkatan Kemampuan Guru Paud Dalam Pengelolaan Pembelajaran Bagi Anak Usia Dini." JURNAL ABDIMAS UMTAS 2, no. 1 (2019).

Elisabeth. Pembelajaran PAK (Pendidikan Agama Kristen) Pada Anak Usia Dini ,. Bandung: Bina Media Informasi, 2009.

Hamdani. Strategi Belajar Mengajar. Bandung: Pustaka Setia, 2011.

Hamruni. Strategi Pembelajaran. Yogyakarta: Insan Madani, 2012.

Hutabarat, Oditha R. Model-Model Pembelajaran Aktif Pendidikan Agama Kristen SD, SMP, SMA Berbasis Komptensi. Bandung: Bina Media Informasi, 2005.

Ismail, Andar. Selamat Menabur. Jakarta: BPK Gunung Mulia, 2017.

Kalis Stevanus. Mendidik Anak. Yogyakarta: Lumela, 2018.

-_- Menjadi Orangtua Bijak: Solusi Mendidik Dan Melindungi Anak Dari Pengaruh Pergaulan Buruk. Yogyakarta: Yayasan Pusataka Nusatama, 2016.

Masitoh. Strategi Pembelajaran TK. Jakarta: Universitas Terbuka, 2005.

Muafiah, Evi. "Strategi Pembelajaran Multiple Intelligences Di TK/RA Ponorogo"." ThufuLA 4, no. 1 (2016).

Non-Serrano, Oditha R. Hutabarat dan Janse Belandina. Pedoman Untuk Guru PAK. Bandung: Bina Media Informasi, 2006.

Saripudin, Aip. "Strategi Edutainment Dalam Pembelajaran Di PAUD (Studi Kasus Pada TK Di Kota Cirebon).” AWLADY: Jurnal Pendidikan Anak Vol. 4, no. No.1 (2018).

Sidjabat, B.S. Strategi Pendidikan Kristen: Suatu Kajian Teologis-Filosofis. Yogyakarta: Andi Offset, 1996.

Sidjabat, B.S. Menjadi Guru Profesional : Sebuah Perspektif Kristiani. Yogyakarta: Andi Offset, 2000.

Sidjabat, B.Samuel. Membesarkan Anak Dengan Kreatif. Yogjakarta: Andi Offset, 2008. Sumiyatiningsih, Dien. Mengajar Dengan Kreatif Dan Menarik: Buku Pegangan Untuk 
Mengajar Pendidikan Agama Kristen. Yogjakarta: Andi Offset, 2007. W, Sri Anitah. Strategi Pembelajaran, 2020.

Windisyahputra. Menghadirkan Lembaga PAUD Ideal. Takengon: Media Utama, 2014. Dirjend PAUD-Dikmas, Kurikulum Pendidikan Anak Usia Dini, Apa, Mengapa Dan

Bagaimana. Jakarta: Jakarta: Dirjen PAUD-Dikmas, 2015.

Jurnal Ilmiah Anak Usia Dini. Jakarta: Dirjen Pendidikan Luar Sekolah, 2003.

PAUD : Investasi Masa Depan Bangsa. Jakarta: Direktorat Jenderal Pendidikan Luar Sekolah, 2006. 